\title{
Revisiting Argentina's Recuperated Factories - Reflections on Over a Decade of Workers' Control
}

AARON TAUSS

\author{
Article Received: March 2, 2014 \\ Article Accepted: May 16, 2014 \\ Doi: dx.doi.org/10.12804/desafios27.01.2015.06
}

How to cite this article: Tauss, A. (2015). Revisiting Argentina's recuperated factories Reflections on over a decade of workers' control. Desafíos, 27(1), 185-205. doi: dx.doi. org/10.12804/desafios27.01.2015.06

\begin{abstract}
More than a decade after Argentina's socio-economic, political and financial collapse in the period 2001-2002, over two bundred recuperated factories currently operate under the direct control of workers. In many cases the recuperations were a direct response to the growing number of bankruptcies and plant closures in the face of deteriorating economic circumstances. The article revisits the workers' struggle and examines the specific socio-historical context that facilitated the emergence of Argentina's recuperated workplaces during the 1990 s and in the aftermath of the country's crisis. It further analyzes the post-crisis policies of stabilization and outlines the movements' present situation. Finally, the document concludes by drawing on Gramsci's observations on factory occupations in post-war Italy and his reflections about the relationship between economic crisis, ideological struggle and social transformation.
\end{abstract}

Keywords: Workers' control, Argentina, Counter-hegemony.

* Assistant Professor, Department of Political Science, Universidad Nacional de Colombia, Medellin, Colombia. E-mail: atauss@unal.edu.co 


\title{
Volviendo a las fábricas recuperadas en Argentina - Reflexiones tras una década de control de los trabajadores
}

\begin{abstract}
Resumen
Más de una década después del colapso socio-económico, político y financiero que sufrió Argentina en el periodo 2001-2002, cerca de doscientas fábricas recuperadas operan en la actualidad bajo el control directo de los trabajadores. En la mayoría de los casos, dichas recuperaciones fueron una respuesta directa ante el creciente número de quiebras y cierres de plantas producto del deterioro de las condiciones económicas. El artículo revisa la lucha de los trabajadores y examina el contexto socio-histórico concreto que facilitó el surgimiento de aquellas iniciativas obreras en Argentina durante la década de los 90 y luego de la crisis multidimensional. Adicionalmente, se analizan las politicas post-crisis de estabilización y se esboza la situación actual en la que se encuentran las fábricas recuperadas. Por último, el documento concluye haciendo uso de las observaciones de Gramsci sobre las ocupaciones de fábricas en la Italia de la post-guerra y sus reflexiones acerca de la relación entre una crisis económica, la lucha ideológica y las posibilidades de transformación social.
\end{abstract}

Palabras clave: Control obrero, Argentina, Contra-hegemonía.

\section{Voltando às fábricas recuperadas na Argentina - Reflexões depois de uma década de controle dos trabalhadores}

\begin{abstract}
Resumo
Mais de uma década depois do colapso socioeconômico, politico e financeiro que sofreu a Argentina no periodo 2001-2002, cerca de duzentas fábricas recuperadas operam na atualidade sob o controle direto dos trabalhadores. Na maioria dos casos, ditas recuperações foram uma resposta direta ante o crescente numero de quebras e fechamentos de plantas produto do deterioro das condições econômicas. O artigo revisa a luta dos trabalhadores e examina o contexto sócio-histórico concreto que facilitou o surgimento daquelas iniciativas obreiras na Argentina durante a década dos 90 e depois da crise multidimensional. Adicionalmente, analisam-se as politicas pós-crise de estabilização e se esboça a situação atual na que se encontram as fábricas recuperadas. Por último, o documento conclui fazendo uso das observações de Gramsci sobre as
\end{abstract}


ocupações de fábricas na Itália da pós-guerra e suas reflexões acerca da relação entre uma crise econômica, a luta ideológica e as possibilidades de transformação social. Palavras-chave: Controle obreiro, Argentina, Contra-hegemonia.

\section{Introduction}

Argentina's occupied and recuperated workplaces seem to have successfully consolidated their struggle, in comparison to the rest of the social protest movements, which emerged during the 1990s and in the aftermath of the country's economic collapse in 2001: the unemployed workers' movements ('piqueteros') are internally fragmented and have in part been co-opted by the government; the garbage collectors ('cartoneros') have remained within a structure of dependency and subordination; the neighborhood assemblies have been reduced to a negligible size; and the swap shop initiatives must be regarded as a failure.

All over Argentina there are currently over 300 worker-controlled enterprises, which employ a total of 13,462 workers in the different sectors of the economy (Programa Facultad Abierta, 2014). The recuperations of abandoned enterprises by the workers were a concrete response to Argentina's drastic neoliberal restructuring, which had begun under military rule in the mid-1970s; the country's deindustrialization and recession after 1998; and the overall trend towards social polarization and rising unemployment. In particular, the liberalization and deregulation of the country's economy and the privatization of public assets under the Menem administration (1989-1999) resulted in a radical cutback of social services, a profound attack on organized labor and massive waves of layoffs, company closures and business bankruptcies (Boris \& Malcher, 2001; Levitsky \& Murillo, 2003; MacEwan, 2002; Rock, 2002).

Despite their relatively small relevance to Argentina's economy in quantitative terms, the recuperated workplaces have a high symbolic value and far-reaching social, political and cultural effects that transcend the national and regional contexts. The particularly new about 
the occupied and recuperated enterprises is the close cooperation and the high levels of collaboration between the different initiatives and their overall organizational structures. ${ }^{1}$ Even though the struggle for economic survival is placed at the centre of the workers' efforts, it is the political and legal battle over issues such as the expropriation of the workplace without compensation and the nationalization under workers' control that has drawn international attention (Aiziczon, 2009; Korol, 2005).

As the horizontal structures and the bottom-up approach present a challenge to the conventional authoritative and vertical forms of sociopolitical and economic organization under capitalism, the workers' activism reformulated questions about self-management, solidarity, collective ownership and participatory democracy. It also triggered debates within social movements, political parties, and the media about how production and society at large should be (re)organized in times of crises (Gaudin, 2004; Petras, 2001; Tilly \& Kennedy, 2005).

\section{Defining workers' control}

Argentina's recuperated, worker-controlled enterprises are usually placed under broad conceptual umbrellas such as "workers' control", "workers' self-management", "solidarity economics", "participatory economics", "social and local economy", "the third sector" or "cooperativism” (Alvater \& Sekler, 2006; Giegold \& Embshoff, 2008; Trinchero, 2009). All concepts refer to specific forms of economic organization, which distinguish themselves from orthodox capitalist companies as they "prioritize social and community oriented goals, show corporate engagement in civic action, dedicate their profits to the community economy and [...] [are] organized cooperatively" (Auinger, 2009, p. 6). Workers' control is characterized by a set of principles such as democratic participation by the workers, collective

\footnotetext{
1 The workers have demonstrated, time and again, their solidarity and political support in the different struggles over the recuperation of abandoned and bankrupt factories. The collaboration between the worker-controlled companies was further reinforced in cultural and educational exchange programs and through the signing of commercial agreements.
} 
ownership, horizontal organizational structures and socio-ecologically sustainable production (Altvater, 2006; Gubitzer, 1989; Mayer, 2006; Programa Facultad Abierta, 2003).Argentina's recuperated enterprises are companies under the workers' collective control that prior to the recuperation operated as private capitalist firms (Programa Facultad Abierta, 2010). They substantively differ from companies that exist under the banner of 'employee ownership', an organizational model that has been increasingly implemented by traditional capitalist firms over the past years. In contrast to recuperated enterprises in Argentina, these companies have failed to fulfill and integrate the aforementioned criteria, as they prioritize profit-making over sociopolitical objectives. Instead of allowing for workers' participation, direct democracy and transparent decision-making, in many cases employee ownership actually resulted in the reduction of the workers' wages (Demirovic, 2007; Nutzinger, 1982).

\section{Contextualizing the workplace recuperations in Argentina}

Following Argentina's bloody experience of military rule, marked by brutal repression against workers, first signs of social unrest reappeared in 1989 when people of the Patagonian province Chubut took to the streets to demand the resignation of their governor. In 1993 social protests against the Menem government intensified in the provinces of Santiago del Estero, Jujuy, La Rioja, Chaco, Corrientes and Tucumán (Sitrin, 2006). In the absence of viable alternatives, unemployed workers became more radicalized and determined to explore new methods of class struggle such as factory occupations and the setting up of road blocks on major national highways.

The pickets became a strategic and powerful means used by a growing number of unemployed workers ('piqueteros') ${ }^{2}$ to increase the pressure on local, provincial and federal authorities (Boris \& Tittor, 2006; Cieza,

2 The piqueteros encompassed different movements of unemployed workers such as the Union of Unemployed Workers (UTD) and the Unemployed Workers' Movement (MTD). See MTD Solano (2003). 
2010; Svampa, 2003). In protest against the neoliberal polices of the Menem administration, the workers' primary demands were the creation of a new social consensus based on solidarity, cooperation and collective ownership of the means of production; the expansion of social services and the improvement of the country's infrastructure; political participation and democratization of social relations; and the persecution of crimes committed during Argentina's military dictatorship (Boris, 2005).

As the number of demonstrations increased during the mid-1990s, popular forces made up of students, workers and famers began to openly confront sent-in riot police in the streets of Argentina. The social protests in Argentina's southern province of Neuquén, particularly in Cutral-Có and the provincial capital city of Neuquén, were tightly linked to the privatization of the national petroleum company YPF (Yacimientos Petroliferos Fiscales) during the period 1994-1995. The privatization resulted in the lay-off of over $80 \%$ of the company's employees and a subsequent rise in the unemployment rate to $35,7 \%$ in both townships in 1996 (Alves de Oliveira, Bayer \& Uriona, 2008; Camarero, Pozzi \& Schneider, 1998).

In light of the rapidly deteriorating socio-economic conditions around the country, the protests increasingly became a struggle for the sheer survival for Argentine workers. The inspiring experience and the effective and innovative forms of social organization, which characterized the uprisings in Cutral-Có and Neuquén, quickly spread to other parts of the country. In the spring of 1996 nationwide riots broke out in other places like Plaza Huincul, Tartagal, Jujuy, La Plata, Buenos Aires and the province of Rio Negro. The uprisings eventually paved the way for the massive wave of protests and the emergence of novel forms of popular organization that would sweep through the country in the consecutive years (Fajn, 2004; Svampa, 2006a).

During that period cultural and sports events, local radio stations, theater groups, rock bands, several political parties and social organizations played a significant role in connecting people and communities in their efforts to voice their grievances and organize mobilizations. 
The federal government responded to the rising number and intensity of the social uprisings with increasing persecution and harassment of political activists. On countless occasions, Argentina's armed forces were deployed to the streets with the objective of breaking up roadblocks and dispersing large crowds of protestors.

The first occupations of factories and enterprises occurred throughout the 1990s in the province of Neuquén as a direct consequence of the aforementioned social uprisings, around the same time when Argentina also witnessed the surfacing of the piqueteros movements (Boris, 2005; Martínez \& Ruggeri, 2010; Petras, 2002; Svampa, 2008; Wolff, 2003). The principal motives of the occupations were similar to those of other protest groups. The neoliberal policies of market liberalization, deregulation and privatization adopted by the Menem administrations during the 1990s, the overvaluation of Argentina's exports as a result of the dollar to peso parity and the increasing numbers of cheap foreign imports were viewed as the main causes for the deteriorating socio-economic conditions (Boris 2006; Raimbeau, 2005; Tittor, 2005).

The occupations of the former workplaces emerged as a direct and need-driven response to the withholding of salaries; the closing of thousands of companies all over the country due to bankruptcy, lack of profitability or unmanageable debt; ${ }^{3}$ and the rising unemployment among Argentina's workers. The tactic of occupying the premises was applied as a strategic means in order to weaken the structural power of capital in its potential use of labor-disciplining measures such as plant closures, investment strikes or workers' lockouts. ${ }^{4}$ Ultimately, it was the former employers who had violated their contractual obligations with the workers by reducing salaries and benefits

\footnotetext{
Fajn et al. (2003) estimate that over the past decades irregularities and fraudulent practices had occurred in $90 \%$ of Argentina's private bankruptcy cases.

4 During the period 2001-2010, 62\% of Argentina's recuperated enterprises were taken over through direct action on part of the former workers. In $73,6 \%$ of these cases, workers resorted to the occupation of the plants, which lasted 161 days on average. $50 \%$ of the total number of recuperated enterprises had to deal with different forms of repression and/or eviction attempts (Programa Facultad Abierta, 2010, p. 15-17).
} 
or by refusing to pay outstanding wages. Against this backdrop, one needs to understand the origin of the workers' decision to adopt a disobedient and proactive stance in the defense of their source of employment (Rebón \& Salgado, 2010).

Following the initial stages of occupation and recuperation, almost all enterprises were subsequently converted into cooperatives. This provided the companies with a legal status and allowed them to operate and produce under more secure circumstances (Vieta, 2009). As part of that process, most of the recuperated workplaces began to pay rent for the occupied premises. In several other cases, the workers demanded the immediate expropriation of the entire enterprise in favor of the community (La Vaca Collective, 2007). In the absence of the former owners, the workers found themselves confronted with an entirely unprecedented situation, which compelled them to develop alternative forms for dealing with the overall organization of a collectively run company.

\section{Argentina's post-crisis management}

Despite the depth and severity of Argentina's crisis, the country has since then witnessed a general continuation of capitalist social relations. Emergency measures taken by the Duhalde government (2002-2003) in the immediate aftermath of the country's collapse, were destined to mitigate an exacerbation of socio-economic conditions and a potential escalation of social protests (Llanos, 2002; Nolte, 2002)..$^{5}$ In addition, the massive $70 \%$ devaluation of the peso in the first half of 2002 significantly contributed to the relatively rapid recovery of Argentina's economy. Despite the widespread fear of a return of hyperinflation, Argentina achieved budgetary surpluses both in the balance of trade and the balance of payments at the end of 2002 (Boris \& Malcher, 2005). ${ }^{6}$

\footnotetext{
5 The measures included direct payments of 150 pesos per month to over two million households and price freezes of basic services and public goods such as electricity, water, telephone, gas, public transportation and railways.

6 In 2003 and 2004 Argentina's economy grew at 8,8\% and 8\% respectively. Yet in 2004,
} 
Due to these emergency measures and an overall improving socioeconomic climate, the intensity and the ability to mobilize considerably declined in the second half of 2002. The Kirchner administration (2003-2007) continued on the reformist path of his predecessor with its focus on the 'normalization' of the post-crisis context in the pursuit of returning to a less laissez-faire capitalism with more regulation and elements of the welfare state. Concrete steps the government took in that process included: the sacking of military officers and members of the police force for crimes and violations committed during the military dictatorship; the modification of laws that prevented the indictment and persecution of military officers which had been promoted during the Alfonsín administration (1983-1989); the taking of a firm stance in the negotiations for debt repayment with multilateral financial debtors; ${ }^{7}$ the mitigation of social tensions facilitated by the economic recovery and the implementation of more progressive policies of redistribution; a move towards a stronger orientation of the productive sector for the partial revival of domestic market demand by public stimulus spending and the increase of monthly wages by 50 pesos; a reinforced commitment to the fight against corruption; and the incorporation of the less radical strands of the social and popular movements (Blomeier, 2004; Katz, 2004; Petras, 2004).

The weakening of social movements and its reduced potential of a more profound social transformation in the immediate post-crisis context, were not merely due to the action taken by the government. Sectarianism and internal fragmentation, the establishment of networks of patronage and client-based co-optation, and myopic

GDP per capita still remained $13 \%$ below the level of 1998, while $45 \%$ of Argentineans found themselves living below the poverty line (Blustein, 2005, p. 204-05). Between October 2002 and December 2004 the poverty rate declined from 57\% to $40 \%$. Unemployment dropped to $15 \%$, yet two million Argentineans received social benefits and were officially registered as employed by the end of 2004 (Boris \& Malcher, 2005, p. 145-46).

7 In the different negotiations with international creditors and the IMF, Argentina ultimately reached a partial cancellation of its external debt. The U.S. government supported Argentina's firm negotiation stance, as the majority of the international lenders affected by the debt moratorium were from Europe, in particular from Germany and Italy (Becker, 2004). 
strategies of political struggle also played a significant role in the disintegration of different social protest movements (Svampa, 2006a). The fragmentation may in part explain the eventual success of the reformist agenda of the Duhalde, Kirchner and Fernandez de Kirchner (2007-present) administrations, all of which were focused on restoring the pre-crisis order (Gago \& Sztulwark, 2009).

In retrospect, Argentina's economic downturn merely represented a temporary hegemonic crisis of the country's neoliberal model and not its irrevocable collapse. The post-crisis governments promoted a process of re-legitimization and mass co-optation and, in large part, eventually succeeded in the construction of a new consensus. With regards to fundamental structural changes in the country's economy since 2002, the recovery has been characterized by a systematic reindustrialization, earmarked funding for small and medium-sized enterprises, the redistribution of incomes to the ruling elites, and an increasing effectiveness of welfare programs (Beccaria \& Groisman, 2006). For Argentina's recuperated workplaces, however, the time since 2003 might be characterized as a period of consolidation, as the number of worker-controlled factories has steadily increased during the past couple of years.

\section{Argentina's recuperated enterprises in the present ${ }^{8}$}

In absolute terms, the economic relevance of the recuperated workplaces within Argentina's post-crisis economy is relatively small. In 2013, 311 recuperated, worker-controlled enterprises existed all across Argentina employing a total of 13,462 workers. With regards to the

\footnotetext{
8 In this section most of the statistical data on Argentina's recuperated enterprises is derived from the Informe del Tercer Relevamiento de Empresas Recuperadas: Las Empresas Recuperadas en la Argentina 2010 (Programa Facultad Abierta, 2010) and the upcoming Informe del Cuarto Relevamiento de Empresas Recuperadas: Las Empresas Recuperadas en la Argentina 2010-2013 (Programa Facultad Abierta, 2014). The reports are the latest of their kind following earlier investigations by the same institution (see Programa Facultad Abierta, 2003, 2005). The initial list of all existing recuperated enterprises in Argentina, which provided the foundation for the subsequent qualitative and quantitative inquiry, was based on the previous work of a wide range of grassroots organizations and research institutes.
} 
geographical distribution, $64,8 \%$ of the recuperated enterprises are located in the province of Buenos Aires and employ 59,7\% of all the workers. Half of all the enterprises operate in the Metropolitan Area of Buenos Aires equaling to $46,9 \%$ of all workers. ${ }^{9}$ In the rest of Argentina, Santa Fe (87\% / 8,9\%) together with Córdoba (4,5\% / 7,5\%), Chaco (2,9\% / 2,5\%), Rio Negro (2,5\% / 1,8\%) and Mendoza $(2.6 \% / 1,8 \%)$, are leading the way of nationwide workplace recuperations.

Argentina's recuperated enterprises differ substantially in size, economic activity and political orientation. $75 \%$ of the enterprises are small and medium-sized companies and employ less than 50 workers. The majority (23.4\%) forms part of Argentina's metallurgy industry, followed by the graphic and design sector $(7,8 \%)$, the textile and meat industry (both 6,3\%), the health care sector $(4,9 \%)$ and the rest of the food industry $(2,7 \%)$. Some enterprises established links to traditional leftist parties and yet others began to work on communityoriented projects by focusing directly on their specific local contexts.

The first organization which began to act as a representative body for the occupied and recuperated enterprises was the Federacion de Cooperativas de Trabajo de la República Argentina (FECOOTRA), which was then followed by the Federación Nacional de Cooperativas de Trabajo en Empresas Reconvertidas (FENCOOTER).$^{10}$ Eventually, in 2002 and 2003 the Movimiento Nacional de Empresas Recuperadas (MNER) and the Movimiento Nacional de Fábricas Recuperadas por los Trabajadores (MNFRT) emerged as the two most active and relevant federations representing the cause of Argentina's recuperated workplaces (La Vaca Collective, 2007). ${ }^{11}$

\footnotetext{
9 The Metropolitan Area of Buenos Aires is divided into the City of Buenos Aires and Greater Buenos Aires. For an in-depth analysis of the recuperated enterprises in the City of Buenos Aires see Salgado (2010).

10 FECOOTRA and FENCOOTER were founded in 1988 and 2002, respectively.

11 Both federations, MNER and MNFRT, emerged during the height of the workplace recuperations during and in the immediate aftermath of Argentina's socio-economic crisis in 2001-2002. See Tauss (2012) for details.
} 
The MNER pursues a strategy outside of Argentina's existing legal framework for the recuperation of enterprises. Its offensive posture is aimed at pushing the Argentine state towards legislative reforms and the implementation of policies that favor the workers' movements. In particular, its efforts are focused on the struggle for the passing of a new national expropriation law, which would extend the temporary periods currently granted by the local authorities. Further demands include a reform of the existing bankruptcy law in favor of working people; increased technological support by the state; enhanced public capital provisions, which would facilitate the repayments of existing debt obligations with local banks; and a public retirement plan and social security benefits for workers in cooperatives. By contrast, the MNFRT is primarily engaged in the legal defense of the cooperatives, the mobilization of popular support in the face of immanent eviction and the coordination of communication among the recuperated workplaces. It strictly focuses on economic and operational matters and does not deal with socio-political and macroeconomic aspects of the movement.

Over the past years a multiplicity of other organizations has surfaced at both the national and provincial level providing the recuperated enterprises with legal, technical and political advice, and thus ensuring the survival of the worker-led initiatives. In particular, the Federación Argentina de Cooperativas de Trabajadores Autogestionados (FACTA), ${ }^{12}$ Asociación Nacional de Trabajadores Augogestionados (ANTA), Federación de Empresas Recuperadas y Cooperativas de Trabajo (FERyCOOTRA), ${ }^{13}$ Unión Obrera Metalúrgica (UOM), Red Gráfica Cooperativa, Mesa de Empresas Recuperadas de Mendoza, Foro de Cooperativas de las Matanza, Unión Productiva de Empresas Autogestionadas (UPEA) and Confederación Nacional de Cooperativas de Trabajo (CNCT) have moved to the very forefront of representing the recuperated workplaces. ${ }^{14}$ Recent attempts aim at the

\footnotetext{
12 FACTA was founded in 2006 as an offshoot of MNER.

13 FERyCOOTRA has unified a host of recuperated enterprises around UOM.

$1478 \%$ of the recuperated enterprises maintain some form of collaboration with one or more of these organizations and movements (Programa Facultad Abierta, 2010, pp. 76-78; Ruggeri, 2009).
} 
national unification of all organizations under the Coordinadora Nacional de Trabajadores Autogestionados (COMA) with the purpose of further strengthening the alliances between the different actors and strands.

\section{Conclusions}

The struggle of Argentina's recuperated workplaces forms part of a wide range of capillary attempts to overcome the democratic deficits of capitalist production and hierarchical intra-company governance, and it simultaneously provides "a possible answer to marginalization, structural unemployment and unequal income distribution" (Auinger, 2009) related to post-Fordist accumulation. In the creation of an alternative social order, workers' struggles such as those of the recuperated factories will play a key role, as success will heavily depend on the strength and the potential of a well-organized global workforce. Within the contemporary context of transnational capitalism organized labor is, however, no longer the only unit of resistance.

Labor movements must form a central building bloc within a broad alliance or coalition of heterogeneous social forces characterized by their flexible internal organizational forms and interrelationships, as well as the collective determination to bring about a significant shift in the existing configuration of power. Meaningful challenges to the status quo require an organic synergy between a wide range of actors such as of progressive social movements, political parties, universities and other educational institutions, grassroots media, and trade unions. (De Angelis, 2003; Deppe, 2011). Strategies of alternative projects need to be directed beyond the mere national context towards the global level where the struggle over hegemony ultimately unfolds. A coordination and co-operation needs to take place between radical counter-hegemonic forces in the industrialized capitalist countries and those in the periphery so that an effective potential that challenges the existing global order can emerge (Svampa, 2006b).

In this context, drawing on Gramsci's writings may open up a set of potential avenues to travel upon. The creation of new forms of social organization and new networks of popular institutions, so his belief, 
would need to be closely related to a dualist organizational structure: (a) workers' councils and other popular organs based on self-management and broad participation, and (b) a democratic revolutionary party organically connected to the grassroots level rather than to an authoritarian vanguard elite. ${ }^{15}$ Gramsci criticized liberal political parties and traditional trade unions for their reformist approach to capitalist domination and exploitation, their narrow political involvement and their overall commitment to the established social order.

From his first-hand experience of the factory councils in Turin between 1919 and 1920, Gramsci saw a great potential in the popular initiatives of workers' control (Ciolli, 2009; Jones, 2006). Workers' councils, he argued, were the primary organizational entities within the struggle against hegemonic rule. They were a sign of a psychological awakening and a first step towards the realization of freedom and the creation of history on part of the workers (Gramsci, 1921). Despite the dialectical relationship between politics and economics, Gramsci believed in the primacy of economics in the sense that the workers' struggle over the control of the means of production would have to unfold prior to the struggle for political power (Boggs, 1976). In the councils, workers would gain full responsibility and direct control over the means of production under a self-imposed, conscious discipline and voluntary commitment. The democratic and solidarity-based organizational setup of workers' council is an institutional representation of collectivity and a concrete expression of the dialectical unification between base and superstructure. With their permanent discussion, assembly meetings, educational and cultural circles, workers' councils can provide a robust institutional basis for democratic participation on a small-scale. Genuine social transformation would hence emerge through self-conscious initiatives on a massive scale and the construction of democratic, solidarity-based structures at the grassroots level.

\footnotetext{
15 Gramsci had a strong anti-elitist conception of political struggle. Contrary to Lenin, he believed that it was neither the vanguard party nor political elites, but rather the oppressed and subordinated strata of society, which must rise up and occupy the leading role in reshaping the course of history.
} 
The struggle for an alternative society is always an ideological process, which must focus on the profound criticism of political, emotional and cultural aspects of the status quo and their substitution by a new culture, new values and new forms of consciousness. In the immediate aftermath of Argentina's economic crisis the objective conditions for a fundamental social transformation almost undeniably existed. Yet it was the absence of ideological alternatives and new popular consciousness that eventually facilitated the relatively rapid restoration of 'stability' and the maintenance of the pre-crisis power structures.

Gramsci dismissed the widely held conviction shared by many Marxists during his time that critical consciousness would emerge almost automatically from the contradictions that existed within the social sphere of capitalist production. In his conception of the struggle for ideological hegemony and state power, Gramsci distinguished between an 'organic' and a 'conjunctual' dimension. While the former referred to a long-term process of challenging ideological hegemony, the latter pointed towards a period of crisis. Gramsci argued that the 'organic' had to precede the 'conjuctucal' dimension for the success of social change and political struggle. He rejected the idea that a cataclysmic event such as a crisis could be a sufficient prerequisite for the formation of critical social awareness.

Different forms of consciousness such as ideas, feelings and believes are concrete political forces, which define the political struggle of the subordinated strata inside a particular social order. With the increasing complexity within 'civil societies', in particular in the most advanced capitalist countries, the struggle over ideological and cultural hegemony will further gain in importance (Boggs, 1976). It is in the sphere of 'civil society' where radical social change must ultimately emerge (Brand \& Sekler, 2009).

Critical academic research focusing on the heterogeneous experiences of Argentina's recuperated enterprises may enhance their collaboration, organization and co-ordination. Moreover, it may facilitate the understanding and encourage reflection on anti-emancipatory aspects of workers' control such as auto-exploitation, the exploita- 
tion of others and the exploitation of nature. The construction of counter-hegemony requires the creation of alternative institutions and intellectual resources within an established hegemonic order and the ability to resist "the pressure and temptation to relapse into pursuit of incremental gains for subaltern groups within the framework of bourgeois hegemony" (Cox 1983; Brand, 2008).

The formation of revolutionary subjectivity on part of the workers would ultimately require a radical shift from a "corporate-economic" consciousness (i.e. the mere economic self-interest of the workers, the focus on secure employment, etc.) to a political one, in which the struggle is directed towards the transcendence of the overall capitalist system. Intellectuals and academic research play a leading role in that process by raising critical awareness and disseminating a popular, counter-hegemonic, ideological and moral framework for action.

\section{References}

Aiziczon, F. (2009). Zanón: Una experiencia de lucha obrera. Buenos Aires: Herramienta.

Altvater, E. (2006). Solidarisches Wirtschaften: prekär oder emanzipativ? In E. Altvater y N. Sekler (Eds.), Solidarische Ökonomie. (pp. 9-21). Hamburg: VSA.

Altvater, E. \& Sekler N. (2006). Solidarische Ökonomie. Hamburg: VSA. Alves de Oliveira, R., Bayer, K. \& Uriona, V. (2008). Solidarische Ökonomie und Soziale Bewegungen: Anregungen aus Lateinamerika. In S. Giegold y D. Embshoff (Eds.), Solidarische Ökonomie im globalisierten Kapitalismus (pp. 155-158). Hamburg: VSA.

Auinger, M. (2009). Introduction: Solidarity Economics: Emancipatory social change or self-help? Journal für Entwicklungspolitik, XXV(3), 4-21.

Beccaria, L. \& Groisman, F. (2006). Inestabilidad, movilidad y distribución del ingreso en Argentina. Revista de la CEPAL 89, 133-156.

Becker, J. (2004). Argentinische Umschuldung: Zwischen Bewahrung von Handlungsspielräumen und liberaler Anpassung. ILA, 277, 45-47.

Blomeier, H. (2004). Neopopulismus als Folge von Institutionenkrise und Staatsversagen am Beispiel Argentiniens. KAS-Auslandsinformation, 1, 44-63. 
Blustein, P. (2005). And the money kept rolling in (and out): Wall Street, the IMF, and the bankrupting of Argentina. New York: Public Affairs.

Boggs, C. (1976). Gramsci's Marxism. London: Pluto Press.

Boris, D. (2005). Piqueteros und Betriebsbesetzer: Soziale Bewegungen in Argentien. Blätter für deutsche und internationale Politik, 4, 474-482.

Boris, D. (2006). Der Neoliberalismus und die Volksbewegungen: Wohin geht die Entwicklung in Lateinamerka? Wissenschaft und Frieden, 2, 6-9.

Boris, D., \& Malcher, I. (2001). Argentinien am Ende der neoliberalen Sackgasse. Z. Zeitschrift Marxistische Erneuerung, 12(48), 47-59.

Boris, D., \& Malcher, I. (2005). Argentinien nach dem Zusammenbruch des neoliberalen Modells. Prokla, 35(1), 131-148.

Boris, D. \& Tittor, A. (2006). Der Fall Argentinien: Krise, soziale Bewegungen und Alternativen. Hamburg: VSA.

Brand, U. (2008). Gegenhegemonie unter "postneoliberalen” Bedingungen: Anmerkungen zum Verhältnis von Theorie, Strategie und Praxis. In C. Butterwege, B. Lösch y R. Ptak (Eds.), Neoliberalismus: Analysen und Alternativen, (pp. 318-334). Wiesbaden: VS.

Brand, U., \& Sekler, N. (2009). Struggling between autonomy and institutional transformations: Social movements in Latin America and the move toward Post-Neoliberalism. In L. Macdonald y A. Ruckert (Eds.), Post-Neoliberalism in the Americas (pp. 54-70). New York: Palgrave Macmillan.

Camarero, H., Pozzi, P., \& Scheider, A. (1998). Unrest and repression in Argentina. New Politics, 7(1/25). Retrieved from http://ww3.wpunj. edu/ newpol/issue25/camare25.htm

Cieza, D. (2010). Argentina ante el bicentenario: La sociedad, el estado y los actores en un país conflictivo. La Plata: Colección Universidad.

Ciolli, V. P. (2009). La autogestión ayer y hoy. Una mirada desde el pensamiento de Antonio Gramsci. In A. Ruggeri (Comp.), La economía de los trabajadores: Autogestión y distribución de la riqueza (pp. 173-193). Buenos Aires: Ediciones de la Cooperativa Chilavert.

Cox, R. W. (1983). Gramsci, Hegemony and International Relations: An Essay in Method. Millennium: Journal of International Studies, 12(2), 162-175.

De Angelis, M. (2003). Reflections on Alternatives, Commons and Communities. The Commoner, 6, 1-13.

Demirovic, A. (2007). Demokeratie in der Wirtschaft: Positionen, Probleme, Perspektiven. Münster: Westfälisches Dampfboot. 
Deppe, F. (2011). Eine Geschichte von Klassenkämpfen: Wandel des Kapitalismus und die Kämpfe der Arbeiterbewegung. Soz̧ialismus, 9, 51-59.

Fajn, G. (2004). Fábricas recuperadas: La organización en cuestión. Retrieved from http://www.iisg.nl/labouragain/documents/fajn.pdf

Fajn, G. (2003). Fábricas y Empresas Recuperadas: protesta social, autogestión y rupturas en la subjetividad. Buenos Aires: Centro Cultural de la Cooperación.

Gago, V., \& Sztulwark, D. (2009). Notes on postneoliberalism in Argentina. In U. Brand y N. Sekler (Eds.), Postneoliberalism: A beginning debate, Development Dialogue No. 51 (pp. 181-192). Uppsala: Dag Hammarskjöld Foundation.

Gaudin, A. (2004). Occupying, resisting, producing: Argentine workers take over abandoned factories. Dollars and Sense, 29-33.

Giegold, S., \& Embshoff, D. (2008). Solidarische Ökonomie im globalisierten Kapitalimus. In S. Giegold y D. Embshoff (eds.), Solidarische Ökonomie im globalisierten Kapitalismus (pp. 11-24). Hamburg: VSA.

Gramsci, A. (1921, 10 de febrero). Workers' Control. L'Ordine Nuovo. Retrieved from http://workerscontrol.blogspot.com/2007/09/gramscion-workers-control.html

Gubitzer, L. (1985). Geschichte der Selbstverwaltung. München: AG SPAK.

Jones, S. (2006). Antonio Gramsci. London and New York: Routledge.

Katz, C. (2004). Der anhaltende Kampf der Piqueteros. Enfoques Alternativos. Retrieved from http://www.ila-bonn.de/artikel/276piqueteros.htm

Korol, C. (2005). Obreros sin patrón. Sistematización de la experiencia de los obreros y obreras de Zanón. Buenos Aires: Madres de Plaza de Mayo.

LaVaca Collective. (2007). Sin Patrón: Stories from Argentina's worker-run factories. Chicago: Haymarket.

Levitsky, S., \& Murillo, M. V. (2003). Argentina weathers the storm. Journal of Democracy, 14(4), 152-166.

Llanos, M. (2002). ¿Reforma política? Lateinamerika Analysen, 2, 136-140.

MacEwan, A. (2002). Economic debacle in Argentina: The IMF strikes again. Dollars and Sense, 22-25.

Martínez, C., \& Ruggeri, A. (2010). Empresas recuperadas: Elementos teóricos para su análisis. In B. Pereyra y P. Vommaro (Comp.), Movimientos sociales y derechos humanos en la Argentina, (pp. 245-260). Buenos Aires: Ciccus. 
Mayer, S. (2006). Solidarische Ökonomie nur lokal? Fair Trade auf globaler Ebene? In E. Altvater \& N. Sekler (Eds.), Solidarische Ökonomie, (pp. 144-155). Hamburg: VSA.

MTD Solano. (2003). Die Zeiten der Bewegung. In U. Brand (Ed.), iQue se vayan todos! Krise und Widerstand in Argentinien (pp. 95-104). Berlin: Situaciones.

Nolte, D. (2002). No tenemos ninguna posibilidad, pero hay que aprovecharla. Lateinamerika Analysen, 2, 141-145.

Nutzinger, H. G. (1982). Mitbestimmung und Arbeiterselbstverwaltung: Praxis und Programmatik. Frankurt and Main: Vereinigung Deutscher Wissenschaftler.

Petras, J. (2001). The Unemployment worker movement in Argentina. Monthly Review. Retrieved from http://www.monthlyreview. org/0102petras.htm

Petras, J. (2002). Rebellion in Argentina: You have to take action from below: Interview with James Petras. International Socialist Review, 21. Retrieved from http://www.isreview.org/issues/21/petras_interview.shtml

Petras, J. (2004). Argentina: From popular rebellion to Normal capitalism. Retrieved from http://www.marxsite.com/petrasargentina.pdf

Programa Facultad Abierta, Facultad de Filosofía y Letras (UBA). (2003). Las empresas recuperadas: Una experiencia de la clase trabajadora argentina. Retrieved from http://www.recuperadasdoc.com.ar

Programa Facultad Abierta, Facultad de Filosofía y Letras (UBA). (2005). Las empresas recuperadas en la Argentina: Informe del segundo relevamiento del Programa Facultad Abierta (SEUBE- Facultad de Filosofía y Letras-UBA). Retrieved from http://www.recuperadasdoc.com.ar

Programa Facultad Abierta, Facultad de Filosofía y Letras (UBA). (2010). Informe el tercer relevamiento de empresas recuperadas por sus trabajadores: Las empresas recuperadas en la Argentina 2010. Retrieved from http:/ /www. recuperadasdoc.com.ar

Programa Facultad Abierta, Facultad de Filosofía y Letras (UBA). (2014). Informe del cuarto relevamiento de empresas recuperadas en la Argentina 2014: Las empresas recuperadas en el periodo 2010- 2013. Retrieved from http:/ / www.recuperadasdoc.com.ar 
Raimbeau, C. (2005). Empresas recuperadas por sus trabajadores: En Argentina, jocupar, resistir, produce! Retrieved from http:/ / www.eldiplo.org/semanales.php3

Rebón, J., \& Salgado, R. (2010). Empresas recuperadas en la Ciudad de Buenos Aires. En Gestión Obrera: Del fragmento a la acción colectiva (pp. 189-208). Montevideo: Nordan.

Rock, D. (2002). Racking Argentina. New Left Review, 17, 55-86.

Ruggeri, A. (2009). Las empresas recuperadas por sus trabajadores, en torno a los problemas y las potencialidades de la autogestión obrera. En A. Ruggeri (Ed.), Las empresas recuperadas: Autogestión obrera en Argentinay América Latina (pp. 11-90). Buenos Aires: Editorial de la Facultad de Filosofía y Letras, Universidad de Buenos Aires.

Salgado, R. (2010). Empresas recuperadas por sus trabajadores: Sociogénesis y desarrollo del proceso en la Ciudad Autónoma de Buenos Aires. Documentos de Jóvenes Investigadores, 24. Buenos Aires: Instituto de Investigación Gino Germani, Facultad de Ciencias Sociales, UBA.

Sitrin, M. (2006). Horizontalism: Voices of the popularpower in Argentina. Oakland and Edinburgh: AK Press.

Svampa, M. (2003). Las dimensiones de las movilizaciones sociales en Argentina: Un balance necesario. Multitudes. Retrieved from http://www. maristellasvampa.net/archivos/ensayo17.pdf

Svampa, M. (2006a). La Argentina: Movimientos sociales e izquierdas. Entre Voces, 5. Retrieved from http://www.maristellasvampa.net/archivos/ ensayo11.pdf

Svampa, M. (2006b). A cinco años del 19/20 de diciembre. Conference paper presented at Encuentro Organizado por el Equipo de Educación Popular "Pañuelos en Rebeldia", 18 ${ }^{\text {th }}$ December 2006. Retrieved from http:// www.maristellasvampa.net/archivos/ensayo35.pdf

Svampa, M. (2008). The End of Kirchnerism. New Left Review, 53, 79-95.

Svampa, M. (2010). Movimientos sociales, matrices socio-políticos y nuevos escenarios en América Latina. One World Perspectives. Working Paper. Retrieved from http://www.maristellasvampa.net/archivos/ ensayo45.pdf

Tauss, A. (2012). Argentina's recuperated workplaces: The emancipatory potential and the limitations of workers' control. In L. López, M. Molina, D. Pardo, J. Piedrahita, L. Rojas, N. Tejada y R. Zelik (Comp.), ¿Otros mundos posibles? Crisis, gobiernos progresistas, alternativas de sociedad 
(pp. 157-170). Medellín: Fundación Rosa Luxemburg, Universidad Nacional de Colombia, Sede Medellín Facultad de Ciencias Humanas y Económicas.

Tilly, C., \& Kennedy, M. (2005). From resistance to production in Argentina: Worker-controlled businesses take the next step. Dollars and Sense, november.

Tittor, A. (2005). Soziale Kämpfe gegen Privatisierung in Lateinamerika. In D. D. Boris, S. Schmalz \& A. Tittor. (Eds.), Lateinamerika: Verfall neoliberaler Hegemonie? (pp. 40-68). Hamburg: VSA.

Trinchero, H. H. (2009). De la exclusión a la autogestión: Innovación social desde la experiencia de las empresas recuperadas por sus trabajadores (ERT). In A. Ruggeri (ed.), La economía de los trabajadores: Autogestión y distribución de la riqueza (pp. 19-48). Buenos Aires: Ediciones de la Cooperativa Chilavert.

Vieta, M. (2009). Algunas dimensiones analíticas sobre las empresas recuperadas. In A. Ruggeri (Ed.), Las empresas recuperadas: Autogestión obrera en Argentina y América Latina (pp. 91-116). Buenos Aires: Editorial de la Facultad de Filosofía y Letras, Universidad de Buenos Aires.

Wolff, J. (2003). Argentinien nach der Krise: Zur erstaunlichen Stabilität der real existierenden Demokratie. H.S.F.K. Standpunkte, 5, 1-12. 
